Board of Governors of the Federal Reserve System

International Finance Discussion Papers

Number 755

January 2003

updated April 2003

Diversification, Original Sin, and International Bond Portfolios

John D. Burger and Francis E. Warnock

NOTE: International Finance Discussion Papers are preliminary materials circulated to stimulate discussion and critical comment. References in publications to International Finance Discussion Papers (other than an acknowledgment that the writer has had access to unpublished material) should be cleared with the author or authors. Recent IFDPs are available on the Web at www.federalreserve.gov/pubs/ifdp/. 


\title{
Diversification, Original Sin, and International Bond Portfolios
}

John D. Burger and Francis E. Warnock*

\begin{abstract}
While there is a severe home bias in U.S. investors' foreign bond portfolios, we find that portfolio weights are greater for countries with more open capital accounts and whose bond returns are less correlated with U.S. returns. Positions in local-currency-denominated bonds are particularly sensitive to past and prospective returns volatility. An analysis of changes in portfolio weights over time indicates that U.S. investors have recently moved out of smaller markets and those with low and declining credit ratings. Our data also allow for an analysis of the size and currency composition of international bond markets. We find that countries with stronger institutions and better inflation performance have larger local currency bond markets. An implication for developing countries is that creditor friendly policies, such as vigilance on the inflation front and the development of strong institutions, can enable local bond market development and may in turn attract global investors.
\end{abstract}

Keywords: portfolio choice, bond market development, flight to quality, home bias, emerging market debt JEL Classification: F30, G11, G15, O16

\footnotetext{
* The authors are, respectively, Assistant Professor at the Sellinger School of Business and Management at Loyola College of Maryland and Economist in the International Finance Division of the Board of Governors of the Federal Reserve System. The authors thank William Griever, Thomas Jans, Denis Petre, and Maria Toyoda for invaluable assistance with data; JP Morgan for providing data on bond returns; and Tamara Hayford and Sara Holland for research assistance. We thank for helpful comments Morris Goldstein, Bill Helkie, Olivier Jeanne, Steve Kamin, Ross Levine, Ugo Panizza, Vincent Reinhart, Charles Thomas, and seminar participants at the IF Monday Workshop, the IMF Research Seminar, Loyola College, and the University of North Carolina. All errors are our own. John Burger acknowledges support from the Sellinger School Junior Sabbatical Program. The views in this paper are solely the responsibility of the authors and should not be interpreted as reflecting the views of the Board of Governors of the Federal Reserve System, or of any other person associated with the Federal Reserve System. Email: jburger@loyola.edu, frank.warnock@frb.gov
} 


\section{Introduction}

The presumption that investors can and do take positions in international bonds is central to many models in economics and finance. International macroeconomic models-from Mundell-Fleming to portfolio balance to new open economy macroeconomic models-typically assume that representative agents can engage in cross-border trading of bonds. ${ }^{1}$ Central to models of consumption smoothing or risk sharing is the presumption of internationally tradable bonds. ${ }^{2}$ And cross-border bond positions are, of course, prevalent in portfolio diversification models.

Comparatively little empirical work, however, has been conducted on the extent and determinants of investors' positions in international bonds. In the Bekaert and Harvey (2003) survey on emerging market finance, the literature on international bonds is presented in just one short subsection and is limited to a discussion of returns. In the Karolyi and Stulz (2002) survey on international asset pricing and home bias, empirical research on international bonds is mentioned only in passing. In the Lewis (1999) survey on home bias, discussion of bonds is limited to noting the Tesar and Werner (1995) evidence that cross-border bond positions are relatively small.

We aim to fill this gap by analyzing U.S. investors' international bond portfolios across 50 countries. Empirical work on international bond portfolios has been impeded by the (lack of ) availability of three vital types of data. First, to analyze bond portfolios, scaling factors - the size of countries' bond markets-are needed. One contribution of this paper is the presentation and analysis of the size of 50 countries' total, localcurrency-denominated, and dollar-denominated bond markets. ${ }^{3}$ Second, until recently accurate estimates of cross-border bond positions did not exist. We use high quality data on

\footnotetext{
1 See Fle ming (1962); Mundell (1963, 1968); Branson and Henderson (1985); Obstfeld and Rogoff (1995); and Lane (2001).

2 See, for example, Obstfeld (1994) and Lewis (1996).

3 One source of information on the size of bond markets across countries is Merrill Lynch's annual Size \& Structure of the World Bond Market. Merrill's data, however, are delineated by currency (i.e,. the U.S. dollar bond market, the sterling market, etc.). For our analysis, we require bond data categorized by the residence of the issuer. Other recent discussions of bond market development include IMF (2002) and Mihaljek, Scatigna, and Villar (2002).
} 
international bond positions from recent benchmark surveys of U.S. investors' holdings. ${ }^{4}$ Third, until recently historical returns data were available for only a few large countries. With the development of emerging market bond indices, some of which began in the early 1990s, we now have sufficient historical time series of bond returns.

Our analysis is relevant for the literatures on portfolio choice, finance and growth, and financial crises. Research on international portfolio choice has focused to date on equity portfolios. What do we learn from analyzing another asset class? Past work suggests that foreign equity investors tend to be momentum traders (Bohn and Tesar (1996); Bekaert, Harvey, and Lumsdaine (2002); Froot, O'Connell, and Seasholes (2001)). Do investors in foreign bonds also chase past returns? Research on finance and growth has focused on equity markets and banking sector development (Levine (1997), Levine and Zervos (1998)). What contribution does an analysis of bond market development offer? Although bonds play an important role in capitalinflows, research on financial crises has yet to focus on local bond markets. The burgeoning literature on 'original sin', for example, has focused exclusively on external bond markets (Eichengreen, Hausmann, and Panizza (2002)). What are the implications for original sin when data on local bond market development are included in the analysis? Our study addresses each of these questions.

We begin in Section 2 by presenting the ex post diversification gains associated with adding foreign bonds to a domestic bond portfolio. This highlights two aspects of international bonds that will influence our analysis of portfolios. First, currency denomination matters. The optimal portfolio rarely includes substantial unhedged positions in localcurrency foreign bonds. That is, over most horizons from one to fifteen years, autarky dominates unhedged positions in a reward-to-risk sense. Not knowing the extent to which investors hedged international bond positions, in our quantitative analysis we use both

\footnotetext{
4 Tesar and Werner (1995) estimate aggregate bond positions for three countries and the U.S. Bureau of Economic Analysis (BEA) presents aggre gate U.S. positions annually. It is well known, however, that estimates of aggregate and, especially, bilateral positions from financial flow data can be extremely inaccurate (Warnock and Cleaver, 2003). See Griever, Lee, and Warnock (2001) for a primer on the benchmark surveys.
} 
hedged and unhedged returns and differentiate between holdings in the issuer's currency (i.e., localcurrency denominated) and holdings in the investor's currency (in this case, dollar denominated).

We provide a formal statistical analysis of the country distribution of U.S. investors' international bond portfolios in Section 3. We find that country weights in U.S. investors' foreign bond portfolios are related to the openness of capital accounts and potential diversification benefits as given by historical correlations. Separating positions by currency, we find for localcurrency-denominated bonds a noteworthy aversion to countries with higher past and prospective returns volatility. In Section 4, our analysis of portfolio reallocations between 1997 and 2001 reveals evidence of a discriminating flight to quality: U.S. investors pulled back from countries with low or declining credit ratings. We analyze reallocations in equity portfolios, too, and find a similar flight to quality. The one notable difference concerns the volatility of past returns: Bond investors flee volatility, but equity investors do not.

Finally, in Section 5 we focus on local bond market development, an important issue facing emerging markets. The debate over 'original sin' is currently focused on external bond markets. We include local bond markets in our analysis and show in our sample of 50 countries-half of which are emerging markets-that countries with more stable policies (as evidenced by more stable inflation) and stronger institutions have greater bond market development. Our results suggest that emerging markets can develop local bond markets and attract global investors with the adoption of creditor friendly policies. Deeper local bond markets would also provide a redundancy of funding sources, something that may well ameliorate financial crises (Greenspan 1999).

\section{Risk and Return Characteristics of International Bond Portfolios}

It is well known that whereas portfolio theory predicts internationally diversified portfolios, investors tend to exhibit a bias towards local or domestic securities. Much of the home bias literature has focused on international equities (see the surveys by Karolyi and Stulz (2002) and Lewis (1999)), but there is also a literature on the potential diversific ation gains from holding international bonds. The 
benefits of including foreign bonds in a portfolio has been documented by Levy and Lerman (1988), Jorion, (1991), and Levich and Thomas (1993), among others.

Figure 1 plots risk-return profiles of hedged (dashed lines) and unhedged (solid lines) bond portfolios for various holding periods ending in December 2001. The foreign portfolio is a valueweighted composition of bonds from Japan, Canada, United Kingdom, and the euro area, where the weights are given by the size of the individual markets as of end-1997. On each dashed and solid line in the figure, portfolios vary from 100 percent US bonds (at the end labeled 'US') to 100 percent foreign bonds (at the end labeled 'ROW'). The figure shows that the ex post gains to international diversification depend crucially on whether foreign bond positions are hedged against currency risk. ${ }^{5}$

For unhedged positions (solid lines), the profiles are downward sloping; an all-US portfolio not only provided a higher return over these holding periods, it did so with less volatility. That unhedged foreign bonds provided a lower return to US investors is clearly sample dependent: December 2001 coincided with the apex of the dollar's six-year appreciation. Levich and Thomas (1993) studied an earlier period (1977 to 1990) and found that US-based investors would have earned higher returns on unhedged foreign bonds than on US bonds. While the slope is sample dependent, the extreme volatility of unhedged foreign bonds is not. Levich and Thomas find that for 1977-1990 currency volatility more than outweighed the increased returns and the optimal (ex post) unhedged bond portfolio would have been composed mainly of U.S. bonds. ${ }^{6}$ Thus, for holding periods ending in 1990 and 2001, it is difficult to see the (ex post) gains to international diversification with unhedged foreign bonds.

\footnotetext{
5 The hedged portfolio assumes a passive all-hedged strategy; active hedging strategies are analyzed in Levich and Thomas (1993).

${ }^{6}$ As pointed out in Levich (2001), a negative covariance between currency and bond returns—caused perhaps by tight monetary policy that results in bond losses but capital inflows that appreciate the currency-would reduce the variance of unhedged foreign currency positions. However, this covariance term is likely orders of magnitude smaller than the variance of the change in the exchange rate. Recent papers on exchange rate volatility include Bayoumi and Eichengreen (1998) and Devereux and Lane (forthcoming).
} 
Profiles for hedged positions (dashed lines) reveal the benefits of international diversification. By eliminating currency risk, hedged foreign bonds clearly dominated unhedged ones in our sample. ${ }^{7}$ Moreover, over these horizons hedged positions dominated a portfolio of only U.S. bonds. This is due to slightly higher historical returns on hedged foreign bonds, but more importantly to the reduction in risk associated with greater diversification. Indeed, if we assume currency risk is completely hedged, the optimal allocation is comprised almost entirely of non-U.S. bonds, in stark contrast to the all US allocation in the optimal unhedged portolio. ${ }^{8}$

The risk-return tradeoff for unhedged positions indicates that global fixed income investors are not sufficiently compensated for the currency risk inherent in local bond markets. This suggests that to attract and keep global investors a country must either have a well developed derivatives market in its currency (so global bond investors can shed the currency risk) or issue in foreign currency (so currency risk, from the perspective of the investor, is eliminated).

What is the actual allocation between U.S. and foreign bonds in U.S. investors' bond portfolios? As of the end of 2001, U.S. positions in foreign bonds amounted to $\$ 502$ billion dollars. U.S. investors' end-2001 positions in U.S. bonds are estimated to be about \$12,020 billion (Thomas and Warnock, 2003). Thus, foreign bonds comprise about 4 percent of the U.S. investors' bond portfolios, down from 6 percent in 1997. In terms of the efficient frontiers of Figure 1, this approaches the all U.S. allocation.

Relative to the size of foreign bond markets—-which comprise about half the global bond market—U.S. positions in foreign bonds are quite small. This represents a large departure from the predicted allocations of the ICAPM and is still more evidence of the home bias in asset positions. In our analysis of U.S. bond portfolios, we will not attempt to model this home bias at the aggregate level. Rather, we aim to explain the country weights in U.S. bond portfolios. We turn to this exercise next.

\footnotetext{
${ }^{7}$ The domination of hedged over unhedged international bond portfolios was also evident in earlier decades and spawned a series of 'free lunch' papers. For opposing views on the apparent free lunch in hedged international bond portfolios, see Rosenberg (1990) and Perold and Shulman (1988).

${ }^{8}$ Foreign portfolios that also include emerging market debt result in broadly similar efficient frontiers, because even though returns on emerging market and industrial country debt are less correlated, emerging market debt is only a small fraction of the global bond market.
} 


\section{Country Weights in International Bond Portfolios}

The framework underlying our empirical investigation of international bond portfolios is the traditional portfolio theory developed by Sharpe (1964) and Lintner (1965). The international version of the capital asset pricing model (ICAPM) predicts that portfolio weights are given by market weights. We seek to explain deviations from ICAPM portfolio weights, or the weight of a country in U.S. portfolios relative to its market's weight in the world market portfolio. As explanatory variables we use candidate causes for deviations from ICAPM weights, such as direct and indirect barriers to international investment. For example, investors might deviate from ICAPM allocations because of direct barriers, such as capital controls or high transaction costs, or indirect barriers, such as information asymmetries. Information asymmetries could, for example, prompt returns-chasing behavior; to allow for such behavior, we examine the extent to which the mean (and volatility) of past returns affects asset allocations.

\subsection{The Dependent Variable}

We aim to explain the country allocation in U.S. investors' foreign bond portfolios. Analogous to the measure of equity home bias used in Dahlquist, Pinkowitz, Stulz, and Williamson (forthcoming) and Ahearne, Griever, and Warnock (forthcoming), the deviation of country $i$ 's weight in U.S. investors' portfolios from its ICAPM weight is given by the following:

DevICAPM $_{i}=\left(\right.$ USHoldings $_{i} /$ US Bond Portfolio $) /\left(\right.$ Bond Market $_{i} /$ World Bond Market $)$

In cross-sectional work, the size of the U.S. bond portfolio relative to the world bond market is a constant equal to about one-half in 2001. Thus, for ease of interpretation we analyze the following measure that is observationally equivalent to equation (1): 
where $i$ denotes the country, $T$ ( $\mathrm{T}=$ total, dollar-denominated, or localcurrency-denominated $)$ is the type of bonds analyzed, and the holdings data are from the 1997 and 2001 comprehensive benchmark surveys of U.S. investors' positions in foreign securities. ShareUS is the relative importance of U.S. investors in the bond market of country $i$, which is observationally equivalent to a home bias or deviation from ICAPM measure and identical to equity measures used in Falkenstein (1996) and Gompers and Metrick (2001).

The denominator of Share $U S_{i}$ requires data on the size and currency composition of foreign bond markets. Our primary source for calculating the size of bond markets is unpublished data from the Bank for International Settlements (BIS). For local-currency bonds that are placed in the domestic market, we use the unpublished data on long-term debt underlying BIS Quarterly Review Table 16A on domestic debt outstanding. For international bonds (i.e., those in foreign currencies or placed abroad), we use the security-level data underlying BIS Quarterly Review Table 14B. The security-level nature of these data allow us to break out issuance by country and by currency, which is essential to our calculation of the size of dollar-denominated debt outstanding by country, but also to capture the local-currency-denominated debt issued abroad. ${ }^{9}$ We will analyze portfolio allocations, so in theory we would like to measure not the size of the entire bond market, but the float, or tradable portion. In the literature on equity portfolios, the size of the tradable market is calculated by excluding shares held by insiders; see, for example, Dahlquist et al. (forthcoming). There is no widely accepted definition of float for bonds, but one approach would be to subtract government agencies' holdings of their own government's bonds. In practice, such information is not available across a wide range of countries, although we are able to exclude a subset of government 
holdings — central bank holdings of their own government's bonds, which are presented for most countries in the IMF's International Financial Statistics (line 12a). Note that this 'float' adjustment affects only local currency issuance; we assume governments do not hold their own foreign-currency-denominated debt.

Summary data for our scale factors - the size of total, localcurrency denominated, and dollar denominated bond markets (excluding central bank holdings) — are displayed in Table 1. We analyze these data in some detail in Section 5. A cursory examination of Table 1 reveals, not surprisingly, that bond market development is much more extensive in industrial countries relative to emerging markets. Between 1997 and 2001 bond markets have grown across the board, with substantial growth in the euro area, Japan, U.K., and Emerging Asia. Local currency and dollar-denominated bond markets each grew over this time period with a notable increase in the share of dollar-denominated issuance.

Summary data for our dependent variable, (scaled) U.S. positions in foreign bonds, are displayed in Table 2. Three facts are immediately evident. First, U.S. investors hold a small and declining portion of the foreign bond market. In our sample of fifty countries, at end-1997 U.S. investors held 3.8 percent of the amount outstanding; by end-2001, U.S. positions fell to only 2.9 percent. These small positions imply a severe home bias, as foreign bonds comprised only 6 percent of the U.S. bond portfolio in 1997 and only 4 percent in 2001, much below their 55 percent share in the world bond market. Second, as a share of amounts outstanding, U.S. positions in dollar-denominated bonds are much greater than their positions in local currency bonds. In 1997, U.S. investors held 28 percent of the dollar-denominated foreign bond market, but only 2 percent of local currency bonds; a similar pattern is evident for 2001. Third, the decline in U.S. holdings from 1997 to 2001 occurred in both dollar and local currency bonds.

\footnotetext{
${ }^{9}$ The BIS security-level international bond data combines information from Capital DATA (Bondware), Thomson Financial Securities Data (Platinum), and Euroclear. BIS then identifies and removes duplicates, corrects mistakes, ensures a consistent classification of issuers across the different sources, and performs general quality control. Thus, it appears to be the most comprehensive data set on international bonds. It does not, however, include information on Brady bonds, which we obtained from Merrill Lynch (2002). BIS data on domestic debt is not collected at the security level but should by definition contain only localcurrency-denominated bonds placed locally; for Argentina and Peru, however, it contains some foreign currency issues, which we have recategorized.
} 
The decline in holdings of dollar-denominated bonds was concentrated in emerging markets, but the decrease in local currency positions was also evident in industrial country bonds.

Perhaps surprisingly, Table 2 shows that U.S. holdings are quite similar across industrial and emerging market countries. Despite the sharp decline in holdings of emerging market debt, as of end2001 U.S. investors held 9.6 percent of the total Latin American bond market, a greater share than in the UK, euro area, or Japan. By end-2001 U.S. investors' holdings of local-currency-denominated debt was low across the board and extremely low in emerging markets. At end-1997, however, U.S. investors held a non-trivial amount of local emerging market debt. At that time, positions in localcurrency Latin American debt were comparable to positions in the UK and exceeded positions in Japan and the euro area.

\subsection{Explanatory Variables}

Table 2 demonstrates that the nature of U.S. positions is somewhat similar across different types of countries. This broad similarity does not preclude important differences across individual countries. To analyze the cross-sectional variation in U.S. bond positions, we first need to identify candidate causes for deviations from the ICAPM allocation. These include:

Historical Performance. Historical risk-return tradeoffs are sample dependent. Nonetheless, the story from the efficient frontiers of Figure 1 is striking. If global bond investors are momentum traders who use past performance as some indication of future performance, historical risk-return tradeoffs could lead to deviations from ICAPM allocations. We construct historical risk and return measures using monthly observations of JPMorgan country-level bond indices. For emerging markets, we use JPMorgan Emerging Market Bond Index (EMBI) Global, which consists of dollar-denominated bonds. For industrial countries we rely on the JPMorgan Government Bond Index (GBI), which consists of government bonds denominated in local currency. Because we are interested in returns to U.S. investors, we utilize GBI returns expressed in dollars. In all, the JPMorgan indices provide coverage for 45 countries in our sample. For each country we calculate the average return (MEAN), variance of return 
(VAR), Sharpe ratio (SHARPE), and correlation with U.S. bond returns (CORR) over a four-year period ending December 2001. ${ }^{10}$

In our empirical work we seek to explain U.S. investors' holdings of total, dollar-denominated, and localcurrency-denominated bonds. It is not, however, always clear which returns series are most appropriate. For total U.S. positions in emerging markets, the vast majority of U.S. investors' emerging market holdings are dollar-denominated, so the EMBI seems appropriate. For total U.S. positions in industrial countries, we use seperate ly both hedged and unhedged returns. For analysis of dollar portfolios in emerging markets, EMBI dollar-denominated returns are clearly appropriate. For industrial countries, returns series on dollar-denominated bonds are not available, so for dollar holdings we utilize hedged returns on local-currency-denominated debt, a reasonable substitute given low hedging costs for these industrial countries. Finally, local currency indexes are not widely available for emerging markets, so for local currency positions we form unhedged returns on local currency bonds by adding currency returns to EMBI bond returns. For local currency holdings in industrial countries, we again use both hedged and unhedged returns, because the extent to which global investors hedge foreign bond positions is an open issue.

Some studies have found that business cycle variables have predictive power for returns (Keim and Stambaugh (1986), Chen (1991), and Ilmanen (1995)). Following these studies, we formed detrended GDP and stock market variables, but these have no explanatory power for holdings across countries and are not reported in what follows.

Liquidity. Investors who value liquidity may be willing to deviate from ICAPM allocations. Unfortunately, a suitable measure of liquidity is not readily available. Measuring the liquidity of an individual bond can be nontrivial; measures of bond market liquidity across our sample of fifty countries are nonexistent. An indication of trading volume would serve as a good proxy for liquidity, but because bond trading is not conducted on organized exchanges, such a measure does not exist at the country level

\footnotetext{
${ }^{10}$ The Sharpe ratio is calculated as $\left(\mathrm{R}_{\mathrm{i}}-\mathrm{R}_{\mathrm{F}}\right) / \sigma\left(\mathrm{R}_{\mathrm{i}}\right)$. One-month U.S. Treasury bill returns from CRSP are used as the risk-free return series.
} 
across many countries. Instead we rely on McCauley and Remolona (2000), who show that size is a reasonable but imperfect proxy for liquidity, and construct a variable, BDDEV, defined as the size of the bond market normalized by GDP. BDDEV can be interpreted in other ways, too. For example, as a measure of bond market development it is akin to measures of stock or financial market development found in Levine and Zervos (1998) and will capture any preference U.S. investors might have for large or small bond markets.

Credit Ratings. Country credit ratings (RATING) can serve two roles in our analysis of bond portfolios. First, they might have predictive power for risk and thus influence portfolio allocations. Second, they may summarize other macroeconomic information (Cantor and Packer, 1996; Ammer, 1998) and thus be particularly useful in an analysis of a relatively small sample; including credit ratings instead of various macroeconomic variables will help preserve degrees of freedom. We translate Standard \& Poor's ratings on long-term foreign-currency denominated debt into a numeric score ranging from one (AAA) to $21(\mathrm{C})$.

Direct Barriers to International Investment. While direct barriers to international investment have fallen greatly over the past few decades, some restrictions still exist. There is no numeric indicator of bond market openness, so we rely on the more general Quinn (1997) measure of capital account openness (OPEN), which is used in Quinn, Inclan, and Toyoda (2001) and ranges from 0 (completely closed) to 4 (completely open). The measure is available only through 1997; if sustained and credible changes in capital account openness are infrequent, this historical measure should be satisfactory.

Real Linkages. The extent of real linkages could affect deviations from ICAPM allocations. As in Ahearne et al (forthcoming) we use as a measure of real linkages TRADE, the importance of trade with the United States (bilateral exports plus imports over GDP).

Summary statistics for the explanatory variables are provided in Tables $3 \mathrm{a}-3 \mathrm{c}$. The tables show that we have a wide range of countries in our study. For example, as a percent of GDP bond market development ranges from 12 percent (Peru) to 423 percent (Luxembourg), while trade with the US ranges from 1 percent (Poland) to 54 percent (Canada). Wide ranges such as these are not necessarily indicative 
of outliers, but in our statistical work that follows we look carefully for outliers that may have disproportionate influence on results. Tables $3 a-3 c$ also indicate that, in our sample, countries with poor credit ratings tended to have more volatile returns that were less correlated with US returns. That is, the correlations between credit ratings and the correlation and variance of past returns are quite high, sometimes exceeding 0.80 in magnitude. In what follows, to avoid instances of strong multicollinearity we will not include these three variables together in a regression.

\subsection{The Determinants of Country Weights}

Table 4 displays regression results for the determinants of end-2001 country weights in US investors' foreign bond portfolios. The holdings data in Table 2 indicated a strong preference for dollardenominated bonds, so a good rule of thumb is that countries that issue more dollar-denominated bonds will have larger relative weights in US portfolios. In columns (1) and (2) we explore other factors of country weights and find that U.S. investors favor bonds from countries with greater bilateral trade linkages (TRADE), more open capital accounts (OPEN), and less correlated returns (CORR). Countries with a more attractive return-risk tradeoff (SHARPE) have greater weights in U.S. portfolios if unhedged returns series are used for industrial countries (column 1), but this result does not hold if hedged returns are used (column 2).

The estimated coefficients are statistically and economically significant. Focusing on colu mn (1), the estimated coefficient for OPEN suggests that U.S. investors' holdings of the Chinese bond market would increase from $0.2 \%$ to $7.7 \%$ if China opened its market (from current level of OPEN of 1.5 to max of 4.0). ${ }^{11}$ The negative and statistically sig nificant coefficient on CORR suggests that U.S. investors' international bond portfolios are more heavily weighted towards countries whose returns are less correlated with U.S. returns, consistent with the theory of portfolio diversification. The estimated CORR coefficient indicates that if a market highly correlated with the U.S. (e.g., Germany) had instead only an

\footnotetext{
11 We recognize that in a general equilibrium world this and other such statements that follow require the ceteris paribus assumption.
} 
average correlation, U.S. investors would have had significantly higher holdings (for Germany, holdings would have doubled from $2.3 \%$ to $4.6 \%$ ). The estimated SHARPE coefficient indicates that Mexico's above average bond performance led US investors to hold 2 percentage points more of outstanding Mexican bonds relative to an average performing market. Finally, the coefficient on TRADE is somewhat less powerful, indicating that a sizable $10 \%$ increase in bilateral trade as a share of GDP would increase holdings by less than 1.5 percentage points. The TRADE result is somewhat tenuous; if Canada is dropped from the regression, TRADE is no longer significant.

In columns (3) and (4) we examine the factors that determine holdings of dollar-denominated bonds. In column (3) only TRADE is significant. While the Sharpe ratio is no longer significant, in column (4) we enter its numerator and denominator separately and find that countries with higher historical returns (MEAN) have greater weights in U.S. portfolios. Again, dropping Canada (not shown) changes the results: TRADE becomes insignificant and CORR is negative and significant.

For localcurrency-denominated bonds, in column (5) only CORR is significant; its sign, however, has switched from negative to positive. An explanation is that in this sample CORR is highly correlated with other variables such as returns performance and capital account openness. Indeed, when we omit CORR in columns (6) and (7), we find roles for variables associated with risk and volatility. U.S. investors avoid the local bond markets with worse credit ratings and higher volatility. In these regressions, New Zealand is a mysterious outlier-US investors hold much more of New Zealand's local currency bond market than any other country's. Omitting New Zealand from the local currency regressions greatly improves the fit but does not substantively change the pattern of results.

The attraction to mean returns in dollar-denominated portfolios and the contrasting aversion to volatility in local currency portfolios is consistent with the distinction between hedged and unhedged bond portfolios made in Section 2. Given the risk associated with unhedged positions in foreign bonds (illustrated in Figure 1), it is not surprising that measures of risk and volatility are more important in explaining holdings of localcurrency denominated debt. For dollar-denominated bonds the primary 
source of volatility has been eliminated, justifying a greater emphasis by U.S. investors on the level of returns.

\section{Reallocations in International Bond and Equity Portfolios}

In this section we shift our attention from holdings at a point in time (end-2001) to changes in portfolio weights from 1997 to 2001. Table 2 showed that between 1997 and 2001 U.S. investors decreased their holdings from 4 percent of outstanding foreign bonds to 3 percent. The bulk of this decline was in emerging market bonds. U.S. investment in Latin American bonds fell from 20 to 9 percent, while investment in emerging Asian bonds deceased from 5 to 1 percent. In contrast, U.S. investors maintained their share of outstanding bonds in industrial countries.

The evidence in Table 2 raises the question of whether U.S. investors blindly dumped emerging market bonds or were more discriminating in their portfolio adjustments. To address this question, we investigate the determinants of changes in U.S. portfolio weights from 1997 to 2001 as defined by:

Dhold $_{i}=\left(\frac{\text { USHoldings }_{i}^{2001}}{\text { MarketSize }_{i}^{2001}}\right)-\left(\frac{\text { USHoldings }_{i}^{1997}}{\text { MarketSize }_{i}^{1997}}\right)$

For comparison, after analyzing the reallocations in international bond portfolios, we update the Ahearne et al (forthcoming) analysis of changes in equity portfolios.

\subsection{Bond Portfolio Reallocations}

Columns (1) - (3) of Table 5 display regression results for the change in total bond holdings on various factors. Since our holdings data are at current value but the issuance data are valued at face, we 
deflate 2001 holdings by the price change from 1997 to $2001 .^{12}$ Our baseline regression (Column 1) indicates that U.S. investors moved into more developed bond markets and away from smaller ones. There is also strong evidence that investors moved away from countries with poor 1997 credit ratings, and more so from those whose credit rating was subsequently downgraded. For example, our coefficients indicate that Malaysia, with its 1997 credit rating of A, would have seen more U.S. disinvestment than a more highly rated country -2.5 percentage points more than a country with a 5-step higher credit rating of AAA. More important, however, was its 3-step downgrade to BBB, accounting for a 3.3 percentage point decrease (of $8.4 \%$ total).

In columns (2) and (3), we find that U.S. investors considered performance measures in their portfolio reallocations. The positive and significant coefficient on SHARPE in column 2 suggests that U.S. investors moved into markets with favorable return-risk ratios. Over this period, poor and declining credit ratings were highly correlated with greater returns volatility; so we do not include the credit ratings variables in regressions with the variance of returns. The results in column (3) suggest that U.S. investors considered both mean and variance in their reallocations.

Our finding that investors sought out more developed bond markets while avoiding credit risks and volatile returns appears to indicate a flight to quality from 1997 to 2001 . This was not, however, a blind dumping of emerging market debt. A binary dummy variable for LDCs (not shown) is negative and highly statistically significant in a bivariate regression — that much was evident from Table 2-but has no effect in our multivariate regressions. This suggests that within the category of LDC debt, U.S. investors considered characteristics such as credit risk when adjusting their portfolios.

\subsection{Equity Portfolio Reallocations}

Our analysis of the change in U.S. investors' international bond portfolios from 1997 to 2001 reveals a flight to quality. The statistical evidence rejects the hypothesis that this was a blind flight from

\footnotetext{
12 We use total returns indexes to deflate holdings. Straight price indexes would be preferable, but they are not available for all countries.
} 
emerging markets and instead supports the notion that U.S. investors considered a number of risk factors when adjusting their portfolios. We now turn to an investigation of the change in U.S. equity holdings over the same period to see if a similar pattern emerges.

Columns (4) - (7) of Table 5 display regression results for the change in equity holdings on various factors. The results are strikingly similar to the results for bond reallocations. For example, U.S. investors moved into more developed equity markets and decreased holdings in countries with poor or declining credit ratings. As with bond portfolios, equity investors moved into the better performing markets. In contrast to the findings for bonds, however, equity investors do not exhibit an aversion to returns volatility; the Sharpe ratio is a significant predictor of the change in equity holdings (column 6), but the explanatory power is in the numerator rather than the denominator (column 7). ${ }^{13}$

As with bond portfolios, the results for equity reallocations raise the question of whether the explanatory variables are simply capturing a flight from emerging market equities. And, as with bond portfolios, an LDC dummy (not shown) is not significant in our multivariate regressions. Consistent with our findings for bonds, these results suggest that within the category of emerging market equities, U.S. investors considered risk and return proxies when adjusting their portfolios.

\section{Bond Market Development and Original Sin}

Our analysis of international bond portfolios indicated that over the past few years U.S. investors have reduced their allocations to smaller bond markets. This raises the question of what determines bond market development. The literature, however, does not provide an unambiguous answer, as bond market development is at the heart of a current debate in academic and policy circles. The catch phrase is “original sin”, which Eichengreen and Hausmann (1999) describes as a situation in which the domestic currency cannot be used to borrow abroad or to borrow long term, even domestically. Under this

\footnotetext{
${ }^{13}$ SHARPE is insignificant when included with the change in credit ratings (column 5), because over this period countries that were downgraded had poor reward-to-risk tradeoffs.
} 
constraint, the fragility of balance sheets—owing to a currency and/or maturity mismatch—can lead a country on a downward spiral of self-fulfilling crises (Krugman, 1999; Schneider and Tornell, 2001; Aghion, Bacchetta and Banerjee, 2001). For example, if firms' assets are in the local currency but they borrow in foreign currency, an exchange rate depreciation immediately and severely worsens balance sheets. Firms then reduce investment, which reduces future output, which in turn generates pressure for further currency depreciation.

If incomplete financial markets are linked to financial instability, as has been suggested in the currency crisis literature, we should aim to determine the source of this emerging market affliction. The phrase "original sin" itself suggests that emerging markets cannot overcome this problem on their own. In support of this notion, Eichengreen, Hausmann, and Panizza (2002), henceforth EHP, find that original sin is exogenous to conditions in developing countries (such as rule of law and past inflation performance) and, therefore, propose an international solution to the problem of original sin. Many papers have followed EHP's lead and assumed original sin is exogenous. For example, Jeanne and Zettelmeyer (2002) start from a situation of original sin and examine solutions that involve international lending.

But are policymakers in emerging markets truly blameless for their fallen state? This question is more than an academic curiosum. If original sin is exogenous, as EHP suggest, international organizations may have an important role in the relief effort. But La Porta et al. (1997) provide evidence that bond market development is positively related to rule of law, which implies that original sin is endogenous (and a misnomer). Based on the La Porta et al. (1997) results, a supranational solution is only second best; the first best solution would address the source of the problem.

One reason for the conflicting results is that EHP and La Porta et al. (1997) use different measures of bond market development. Our data on bond market development shed light on this controversy. To illustrate some nuances of the bond market data, Table 6 provides a comparison of bond market development in Argentina, Chile, and the UK. EHP focus on the currency composition of a country's external bonds (i.e., bonds placed in external markets); the second column displays (one minus) 
an EHP measure of original sin, namely the fraction of each country's external bonds that is denominated in local currency. An expanded measure would also include information on the domestic bond market; column 4 shows the local currency share once domestic bond markets are included. Note that focusing strictly on external bonds would ignore the fact that Chile has a more extensive domestic bond market than Argentina. Even this expanded currency share measure can be a bit deceiving, as it places Chile and the UK on equal footing. More informative than the local currency share of a country's bond market is the actual development of the local currency bond market, which we display in the final column, as the size of a nation's localcurrency-denominated bond market (excluding central bank holdings) divided by GDP. This is closest in spirit to the measure in La Porta et al. (1997), although they focus on private sector bonds and include bank debt. We believe this last measure gets to the heart of the issue: It takes a mature localcurrency bond market to be free from original sin. ${ }^{14}$

In Table 7a we formally investigate the determinants of localcurrency bond market development, expressed as a share of GDP. Table 7a shows that original sin should not be considered exogenous: Institutions and past policy play prominent roles in explaining the cross-country variation in local currency bond market development. In our sample, countries with lower or less volatile inflation over the past ten years (and thus likely more stable monetary and fiscal policies) and stronger institutions (i.e., stronger rule of law) have better developed bond markets. ${ }^{15}$ In addition, the level of economic development, as measured by GDP per capita, is significantly related to bond market development.

Our results in Table 7a contrast sharply with those in EHP. One reason might be that our bond market development measure is different. In Table $7 \mathrm{~b}$ we analyze the share of bonds denominated in the local currency, which is similar in nature to a measure of original sin used in EHP. Again, we find an important role for past inflation. Countries that have had higher or more variable historic inflation tend to

\footnotetext{
14 The skeptic might argue that local currency emerging bond markets are irrelevant because global investors do not participate in them. Table 2 shows, however, that at end-1997 US investors' held a nontrivial amount of localcurrency emerging market bonds.

${ }^{15}$ The Rule of Law variable is, as reported in La Porta et al. (1997), an average over 1982-1995 of the International Country Risk Guide assessment of law and order tradition. We supplement this source with 2000 data from
} 
issue a higher share of foreign-currency-denominated debt. This suggests, as in the model of Jeanne (2002), an important role for monetary policy credibility in explaining the currency composition of a country's debt. Interestingly, per capita GDP and rule of law, which have significant explanatory power for bond market development, are not significant in these regressions, suggesting that the primary distinction between emerging markets and industrial countries is the level of overall bond market development, not the currency denomination of outstanding debt.

As a robustness check, Tables $8 \mathrm{a}$ and $8 \mathrm{~b}$ present the same regressions but excluding some outliers. For example, our results in Table $7 \mathrm{a}$ and $7 \mathrm{~b}$ might be affected by Brazil, Russia, and Turkey, who had extremely high inflation during our sample period, or by Luxembourg, whose bond market development (expressed as a percent of GDP) is more than three times greater than the country with the next most developed market. Excluding the outliers results in different coefficient estimates but has little effect on the statistical signific ance. Variables that are significant in Table 7 tend to be so in Table 8, with one notable exception. In Table 8a, GDP is significant, but it is not in Table 7a. The difference is due to Luxembourg; including Luxembourg, a small country with a very large bond market, renders GDP insignificant.

The results presented in this section have important implications for the current debate. Rather than being a mystery, we find that original sin is related to the macroeconomic and institutional setting in emerging markets. Local bond market development is greater in countries with lower historic inflation and stronger rule of law. For example, the coefficient estimates in Table 8a imply that (ceteris paribus) if Indonesia had Denmark's rule of law, its bond market as a share of GDP would be 36 percentage points higher. If Indonesia had Denmark's inflation history, its bond market would be 16 percentage points (of GDP) larger. These amounts are both economically significant—Indonesia's bond market is currently only 16 percent of GDP — and suggest an important role for creditor friendly policies in emerging markets. There may also be virtuous interactions between the development of the bond market and future

Economic Freedom of the World Annual Report (2002) for six other countries: China, Czech Republic, Hungary, Poland, Russia, and Iceland. 
inflation performance, as Eichengreen and Hausmann (1999) suggest that a well-developed domestic bond market may generate a political constituency opposed to inflationary policies.

\section{Conclusion}

Our aim in this paper is to describe and understand country weights in U.S. investors' international bond portfolios. In doing so we find that important factors include the openness of capital accounts and potential diversification benefits as given by historical correlations. We fine-tune the analysis by separating dollar and local currency portfolios and find that for positions in local-currencydenominated bonds there is a noteworthy emphasis on measures of past and prospective volatility. Our analysis of portfolio reallocations from 1997 to 2001 reveals a flight to quality—not a blind one, but a discriminating flight from those countries with poor or declining credit ratings. The reader should note that our results indicate that U.S. investors do not flee volatility in emerging equity markets. There are at least two possible reasons for this. First, stock market volatility is by no means restricted to emerging economies. Also, the effect of exchange rate changes on the equity of a firm that may well derive a substantial portion of its income from abroad is ambiguous.

To carry out the goal of this paper required measures of the size of bond markets across many countries. No such measures existed, so another contribution of this paper is our presentation of the size and currency composition of bond markets across 50 countries. This in itself has implications for a number of literatures. The empirical literature on finance and growth, which has hitherto excluded bond market development in its analysis, might begin to include debt markets. Perhaps more important is our potential contribution to the 'original sin' literature, which has focused to date on bonds placed abroad. Our analysis of emerging local bond markets suggests a refinement of the original sin hypothesis. The share of a country's overall bond issuance that is denominated in its local currency does not differ substantively between emerging and more developed markets. The legacy of original sin is, rather, that 
emerging bond markets are in general much less developed. We find, moreover, that the cause is not a mystery, but related to policies of the not-so-distant past.

Looking at the trends in the data, we find mixed evidence regarding the prospects for absolution of original sin. While localcurrency-denominated debt in emerging markets, especially in Asia, grew substantially between 1997 and 2001, U.S. positions in such debt dropped precipitously. The question going forward is whether this represents a temporary flight to quality or a more permanent change in preferences.

Our results indicate that U.S. investors consider credit risk and historical returns performance when making portfolio allocation decisions, suggesting that the level of foreign participation in emerging markets is endogenous to conditions in a particular country. The adoption of creditor friendly policies should therefore allow for greater development of local currency bond markets in emerging markets and attract greater levels of foreign participation. Furthermore, local bond market development can lead to the creation of a yield curve and derivative instruments that enable the decoupling of the bond and currency investment. ${ }^{16}$

Finally, some limitations of our study should be noted. We caution readers that our currencyspecific results may not tell the complete story. For both issuance and portfolios, we know the currency denomination but not whether the bonds are indexed to inflation or an exchange rate; some of the bonds included in our local currency analysis, especially for Latin America, may behave a lot like foreign currency securities. On the portfolio side, we do not want to imply that our study speaks to the currency exposure of U.S. investors; not knowing the extent of derivatives positions, for example, makes our snapshot of currency exposure incomplete. And it should be noted that we have said nothing about the quality of bond market development. Historically, an important impetus for financial market development has been exceptional government financing needs, for example to finance large budget deficits that were often incurred to fund a war effort (Rousseau and Sylla, 2001). Indeed, some of the

\footnotetext{
16 Many others promote local bond market development. For example, it figures prominently in the plan put forward in Goldstein (2002).
} 
recent bond market development may be financing large budget deficits. Impavido, Musalem, and Tressel (2002) examine a more benign driver of financial market development, the growth of local contractual savings institutions such as pension funds and life insurance companies. We leave for further work an analysis of the quality of bond market development. 


\section{References}

Aghion, P., P. Bacchetta, and A. Banerjee, 2001. A Corporate Balance Sheet Approach to Currency Crises. Working Paper No. 01.05 (Studienzentrum Gerzensee).

Ahearne, A., W. Griever, and F. Warnock, forthcoming. "Information Costs and Home Bias: An Analysis of U.S. Holdings of Foreign Equities," Journal of International Economics.

Ammer, J., 1998. Sovereign Credit Ratings and International Debt Markets. mimeo, Board of Governors of the Federal Reserve System.

Bayoumi, T., and B. Eichengreen, 1998. Exchange rate volatility and intervention: implications of the theory of optimum currency areas. Journal of International Economics 45: 191-209.

Bekaert, G., and C. Harvey, 2003. Emerging Market Finance. Journal of Empirical Finance vol. 10(1/2).

Bekaert, G., C. Harvey, and R. Lumsdaine, 2002. The Dynamics of Emerging Market Equity Flows. Journal of International Money and Finance 21, 295-350.

Bohn, H., and L. Tesar, 1996. U.S. Equity Investment in Foreign Markets: Portfolio Rebalancing or Return Chasing? American Economic Review 86(2), 77-81.

Branson, W. and D. Henderson, 1985. The Specification and Influence of Asset Markets," in Handbook of International Economics. Vol. 2. Eds.: R. Jones and P. Kenen. Amsterdam, Elsevier Press.

Cantor, R., and F. Packer, 1996. Determinants and Impact of Sovereign Credit Ratings. FRBNY Economic Policy Review 37-53.

Chen, N., 1991. Financial Investment Opportunities and the Macroeconomy. Journal of Finance 46(2): 529-554.

Dahlquist, M., L. Pinkowitz, R. Stulz, and R. Williamson, forthcoming. Corporate Governance and the Home Bias. Journal of Financial and Quantitative Analysis.

Devereux, M., and P. Lane, forthcoming. Understanding bilateral exchange rate variability. Journal of International Economics.

Eichengreen, B., and R. Hausmann, 1999. Exchange Rates and Financial Fragility. NBER WP\#7418.

Eichengreen, B., R. Hausmann, and U. Panizza, 2002. Original Sin: The Pain, the Mystery, and the Road to Redemption. Paper Presented at the IADB Conference "Currency and Maturity Matchmaking: Redeeming Debt from Original Sin."

Falkenstein, E., 1996. Preferences for Stock Characteristics As Revealed by Mutual Fund Portfolio Holdings. Journal of Finance 51(1): 111-135.

Fleming, M., 1962. Domestic Financial Policies Under Fixed and Under Floating Exchange Rates. International Monetary Fund Staff Papers 9: 369-79.

Froot, K., P. O'Connell, and M. Seasholes, 2001. The Portfolio Flows of International Investors. Journal of Financial Economics 59: 151-194. 
Goldstein, M., 2002. Managed Floating Plus. Institute for International Economics, Washington DC.

Gompers, P., and A. Metrick, 2001. Institutional Investors and Equity Prices. Quarterly Journal of Economics (February) 229-259.

Greenspan, A., 1999. Lessons from the Global Crises. Remarks before the World Bank Group and International Monetary Fund, Annual Meetings Program of Seminars, Washington, September 27.

Griever, W., G. Lee, and F. Warnock, 2001. The U.S. System for Measuring Cross-Border Investment in Securities: A Primer with a Discussion of Recent Developments. Federal Reserve Bulletin (October).

Ilmanen, A., 1995. Time-varying expected returns in international bond markets. Journal of Finance 50: 481-506.

Impavido, G., A. Musalem, and T. Tressel, 2002. The Impact of Contractual Savings Institutions on Securities Markets. Mimeo, World Bank and International Monetary Fund.

International Monetary Fund, 2002. Emerging Local Bond Markets. Global Financial Stability Report (September, Chapter 4).

Jeanne, O., 2002. Why do emerging economies borrow in foreign currency? Paper Presented at the IADB Conference "Currency and Maturity Matchmaking: Redeeming Debt from Original Sin."

Jeanne, O., and J. Zettelmeyer, 2002. "Original Sin," Balance Sheet Crises, and the Roles of International Lending. IMF Working Paper WP/02/234.

Jorion, P., 1991. International Bonds: The Asset Class. in R. Aliber and B. Bruce (eds.) Global Portfolios. Homewood, IL: Business One Irwin.

Karolyi, G.A., and R. Stulz, 2002. Are financial assets priced locally or globally? NBER WP\#8994.

Keim, D., and R. Stambaugh, 1986. Predicting returns in the stock and bond markets. Journal of Financial Economics 17: 357-390.

Krugman, P., 1999. Balance Sheets, The Transfer Problem, and Financial Crises. In Isard, P., A. Razin, and A. Rose (eds.) International Finance and Financial Crises: Essays in Honor of Robert P. Flood, Jr. (Boston: Kluwer Academic; Washington: IMF).

Lane, P., 2001. “The New Open Economy Macroeconomics: A Survey.” Journal of International Economics 54(2): 235-266.

La Porta, R., F. Lopez-de-Silanes, A. Shleifer, R. Vishny, 1997. Legal Determinants of External Finance. Journal of Finance 52(3): 1131-1150.

Levich, R., 2001. International Financial Markets: Prices and Policies ( $2^{\text {nd }}$ edition). Boston: McGrawHill Irwin.

Levich, R., and L. Thomas, 1993. The merits of active currency risk management: evidence from international bond portfolios. Financial Analysts Journal 49(5): 63-70. 
Levine, R., 1997. Financial development and economic growth: Views and agenda. Journal of Economic Literature 35: 688-726.

Levine, R., and S. Zervos, 1998. Stock markets, banks, and economic growth. American Economic Review 88(3): 537-588.

Levy, H., and Z. Lerman, 1988. The benefits of international diversification in bonds. Financial Analysts Journal 44(5): 56-64.

Lewis, K., 1996. "What can explain the apparent lack of international consumption risk sharing?" Journal of Political Economy 104: 267-97.

Lewis, K., 1999. "Trying to Explain the Home Bias in Equities and Consumption," Journal of Economic Literature, 37: pp. 571-608.

Lintner, J., 1965. The valuation of risky assets and the selection of risky investment in stock portfolio and capital budgets. Review of Economics and Statistics, 47: 103-124.

McCauley, R., and Remolona, E., 2000. Size and liquidity of government bond markets. BIS Quarterly Review (November).

Merrill Lynch, 2002. The Size and Structure of the World Bond Market: 2001.

Mihaljek, D., M. Scatigna, and A. Villar, 2002. Recent Trends in Bond Markets. BIS Papers No 11.

Mundell, R., 1963. Capital Mobility and Stabilization Policy Under Fixed and Flexible Exchange Rates. Canadian Journel of Economics 29:475-85. , 1968. International Economics. New York: MacMillan.

Obstfeld, M., 1994. "Risk-taking, global diversification and growth." American Economic Review 85: 1310-29.

Obstfeld, M., and K. Rogoff, 1995. "Exchange Rate Dynamics Redux.” Journal of Political Economy 103: $624-660$.

Perold, A., and E. Shulman, 1988. The free lunch in currency hedging: implications for investment policies and performance standards. Financial Analysts Journal 44(4): 45-50.

Quinn, D., 1997. “The Correlates of Changes in International Financial Regulation,” American Political Science Review, 91: pp. 531-551.

Quinn, D., C. Inclan, and M. Toyoda, 2001. How and where capital account liberalization leads to growth. Working Paper, Georgetown University.

Rosenberg, M., 1990. Why there is no free lunch in currency hedging. in L. Thomas (ed.) The CurrencyHedging Debate. London: IFR Publishing.

Rousseau, P. and R. Sylla, 2001. Financial Systems, Economic Growth, and Globalization. NBER Working Paper \#8323. 
Schneider, M., and A. Tornell, 2001. Boom Bust Cycles and the Balance Sheet Effect. mimeo, UCLA.

Sharpe, W., 1964. Capital asset prices: A theory of market equilibrium under the condition of risk. Journal of Finance, 19: 425-442.

Tesar, L., and I. Werner, 1995. Home bias and high turnover. Journal of International Money and Finance 14, 467-493.

Thomas, C., and F. Warnock, 2003. International Equity and Bond Portfolios. mimeo, Federal Reserve Board.

Treasury Department, 1998. Report on Foreign Portfolio Investment in the United States as of December 31, 1997.

Warnock, F., and C. Cleaver, 2003. Financial Centers and the Geography of Capital Flows. International Finance vol. 6(1). 
Table 1. Bond Market Development (amount outstanding)

\begin{tabular}{|c|c|c|c|c|c|c|c|c|c|c|c|c|}
\hline \multirow{6}{*}{$\begin{array}{l}\text { Euro Area } \\
\text { Japan } \\
\text { UK } \\
\text { Canada }\end{array}$} & \multicolumn{4}{|c|}{$\begin{array}{c}\text { Total } \\
\text { (\$ billions and as a } \% \text { of GDP) }\end{array}$} & \multicolumn{4}{|c|}{$\begin{array}{l}\text { Local-Currency-Denominated } \\
\text { ( } \$ \text { billions and as a \% of Total) }\end{array}$} & \multicolumn{4}{|c|}{$\begin{array}{c}\text { Dollar-Denominated } \\
\text { (\$ billions and as a } \% \text { of Total) }\end{array}$} \\
\hline & \multicolumn{2}{|c|}{1997} & \multicolumn{2}{|c|}{2001} & \multicolumn{2}{|c|}{1997} & \multicolumn{2}{|c|}{2001} & \multicolumn{2}{|c|}{1997} & \multicolumn{2}{|c|}{2001} \\
\hline & 5,746 & $88 \%$ & 6,591 & $108 \%$ & 5,037 & $88 \%$ & 5,806 & $88 \%$ & 229 & $4 \%$ & 329 & $6 \%$ \\
\hline & 3,625 & $84 \%$ & 4,382 & $105 \%$ & 3,524 & $97 \%$ & 4,317 & $99 \%$ & 62 & $2 \%$ & 44 & $1 \%$ \\
\hline & 830 & $63 \%$ & 1,297 & $91 \%$ & 665 & $80 \%$ & 956 & $74 \%$ & 89 & $11 \%$ & 195 & $24 \%$ \\
\hline & 568 & $89 \%$ & 630 & $89 \%$ & 421 & $74 \%$ & 441 & $70 \%$ & 108 & $19 \%$ & 149 & $26 \%$ \\
\hline Latin America & 429 & $23 \%$ & 489 & $28 \%$ & 188 & $44 \%$ & 203 & $41 \%$ & 206 & $48 \%$ & 227 & $53 \%$ \\
\hline Emerging Asia & 571 & $19 \%$ & 1,040 & $34 \%$ & 434 & $76 \%$ & 989 & $95 \%$ & 108 & $19 \%$ & 125 & $22 \%$ \\
\hline Other & 1,278 & & 1,380 & & 1,005 & & 924 & & 129 & & 201 & \\
\hline Total $^{\mathbf{a}}$ & 13,048 & $65 \%$ & 15,809 & $81 \%$ & 11,274 & $86 \%$ & 13,637 & $86 \%$ & 930 & $7 \%$ & 1,271 & $10 \%$ \\
\hline Memo: US & 9,917 & $120 \%$ & 13,879 & $136 \%$ & 9,780 & $99 \%$ & 13,589 & $98 \%$ & & & & \\
\hline
\end{tabular}

${ }^{\text {a }}$ Total consists of the 50 foreign countries included in this study.

Notes. Data on \$-denominated bonds and notes are from security-level data underlying BIS Table 14B (International Bonds and Notes by Country of Residence). Localcurrency-denominated debt is the sum of the long-term debt component of BIS Table 16A (Domestic Debt Securities) and the local currency portion of Table 14B less central bank holdings of own country's bonds (primarily from IMF IFS line 12a). Domestic debt for countries not available on Table 16A is from the IMF's Government Finance Statistics Yearbook and Merrill Lynch (2002). 
Table 2. U.S. Holdings of Foreign Bonds (\$billions and \% of outstanding)

\begin{tabular}{|c|c|c|c|c|c|c|c|c|c|c|c|c|}
\hline \multirow[b]{3}{*}{ Euro Area } & \multicolumn{4}{|c|}{ Total } & \multicolumn{4}{|c|}{ Local-Currency-Denominated } & \multicolumn{3}{|c|}{ Dollar-Denominated } & \\
\hline & \multicolumn{2}{|c|}{1997} & \multicolumn{2}{|c|}{2001} & \multicolumn{2}{|c|}{1997} & \multicolumn{2}{|c|}{2001} & \multicolumn{2}{|c|}{1997} & \multirow{2}{*}{$\underset{*}{2001}$} & \\
\hline & 115 & $2.0 \%$ & 137 & $2.1 \%$ & 71 & $1.4 \%$ & * & * & 35 & $15.2 \%$ & & * \\
\hline Japan & 30 & $0.8 \%$ & 25 & $0.6 \%$ & 23 & $0.6 \%$ & * & * & 4 & $5.9 \%$ & * & * \\
\hline UK & 54 & $6.5 \%$ & 72 & $5.6 \%$ & 23 & $3.5 \%$ & * & * & 26 & $29.6 \%$ & * & * \\
\hline Canada & 106 & $18.6 \%$ & 105 & $16.6 \%$ & 42 & $9.9 \%$ & * & * & 56 & $52.4 \%$ & * & * \\
\hline Latin America & 91 & $21.1 \%$ & 47 & $9.6 \%$ & 6 & $3.0 \%$ & * & * & 77 & $37.5 \%$ & * & * \\
\hline Emerging Asia & 35 & $6.2 \%$ & 14 & $1.2 \%$ & 2 & $0.4 \%$ & * & * & 31 & $28.5 \%$ & * & * \\
\hline Other & 63 & & 52 & & 25 & & * & & 32 & & * & \\
\hline Total $^{a}$ & 494 & $3.8 \%$ & 452 & $2.9 \%$ & 191 & $1.7 \%$ & * & * & 261 & $28.1 \%$ & * & $x$ \\
\hline Total Foreign & 547 & & 502 & & & & * & & & & * & \\
\hline Memo: US & 8,641 & $87 \%$ & 12,020 & $73 \%$ & & & & & & & & \\
\hline
\end{tabular}

${ }^{\text {a }}$ Total consists of the 50 foreign countries included in this study.

* 2001 data by currency are used in the subsequent empirical work but cannot be displayed until the official data release, scheduled for May 2003.

Notes. Holdings data for foreign bonds are from the 1997 and 2001 benchmark surveys of U.S. Holdings of Foreign Securities, available at www.treas.gov/fpis/. Estimates of U.S. holdings of U.S. bonds are formed by subtracting foreign holdings of U.S. bonds, as estimated in Thomas and Warnock (2003), from the amount of U.S. bonds outstanding. 
Table 3. Summary Statistics

(a) Total Bond Holdings

\begin{tabular}{|c|c|c|c|c|c|c|c|c|c|c|c|c|c|}
\hline & Mean & Standard & Min & Max & Nobs & t-stat & & & & Correlat & & & \\
\hline & & & & & & & BdDev & Trade & Rating & Open & USharpe & UVar & UMean \\
\hline BdDev & 0.722 & 0.681 & 0.121 & 4.230 & 48 & -0.398 & & & & & & & \\
\hline Rating & 6.521 & 5.411 & 1 & 20 & 48 & +0.945 & -0.49 & -0.01 & & & & & \\
\hline Open & 3.185 & 0.839 & 1.5 & 4 & 46 & +1.914 & 0.35 & 0.02 & -0.53 & & & & \\
\hline USharpe & 0.014 & 0.181 & -0.238 & 0.505 & 44 & +0.747 & -0.39 & 0.02 & 0.52 & -0.61 & & & \\
\hline UVar & 0.002 & 0.002 & 0.000 & 0.010 & 44 & +0.408 & -0.27 & -0.06 & 0.75 & -0.18 & -0.07 & & \\
\hline UMean & 0.004 & 0.007 & -0.017 & 0.033 & 44 & +0.563 & -0.26 & 0.11 & 0.34 & -0.61 & 0.82 & -0.11 & \\
\hline UCorr & 0.255 & 0.301 & -0.333 & 0.588 & 44 & -1.551 & 0.41 & -0.14 & -0.76 & 0.55 & -0.36 & -0.59 & -0.48 \\
\hline
\end{tabular}

\begin{tabular}{|l|l|l|l|l|l|l|l|l|l|l|l|l|l|}
\hline & & & & & & & & & & HSharpe & HVar & HMean \\
\hline HSharpe & 0.174 & 0.127 & -0.218 & 0.505 & 42 & -0.899 & 0.17 & -0.07 & -0.41 & -0.05 & \\
\hline HVar & 0.002 & 0.003 & 0.000 & 0.010 & 42 & +0.546 & -0.34 & -0.02 & 0.83 & -0.24 & -0.68 & & \\
\hline HMean & 0.007 & 0.006 & -0.017 & 0.033 & 42 & +0.048 & -0.06 & 0.06 & -0.02 & -0.42 & 0.68 & -0.30 & \\
\hline HCorr & 0.342 & 0.390 & -0.333 & 0.778 & 42 & -0.829 & 0.52 & -0.06 & -0.83 & 0.57 & 0.38 & -0.64 & -0.23 \\
\hline
\end{tabular}

Notes. Variables are for 2001 except Open, which is for 1997, and returns-based variables, which are computed over the period 1998-2001. U(H) indicates industrial country returns are unhedged (hedged). Returns for emerging markets are based on dollar-denominated bonds comprising the EMBIG indexes. Russia and Ecuador are omitted because of lack of data for explanatory variables. T-stat is the t-statistic from a regression of holdings on the characteristic (and a constant). 


\section{(b) Holdings of Dollar-Denominated Bonds}

\begin{tabular}{|c|c|c|c|c|c|c|c|c|c|c|c|c|c|}
\hline & Mean & $\begin{array}{l}\text { Standard } \\
\text { Error }\end{array}$ & Min & $\operatorname{Max}$ & Nobs & t-stat & \multicolumn{7}{|c|}{ Correlations } \\
\hline & & & & & & & BdDev & Trade & Rating & Open & HSharpe & HVar & HMean \\
\hline BdDev & 0.737 & 0.700 & 0.121 & 4.230 & 45 & +1.771 & & & & & & & \\
\hline Trade & 0.109 & 0.116 & 0.010 & 0.544 & 45 & +1.673 & -0.11 & & & & & & \\
\hline Rating & 6.178 & 5.331 & 1 & 20 & 45 & -0.544 & -0.48 & 0.02 & & & & & \\
\hline Open & 3.279 & 0.781 & 1.5 & 4 & 43 & +1.481 & 0.35 & -0.01 & -0.48 & & & & \\
\hline HSharpe & 0.168 & 0.118 & -0.218 & 0.475 & 40 & +0.267 & 0.22 & -0.06 & -0.58 & 0.07 & & & \\
\hline HVar & 0.002 & 0.003 & 0.000 & 0.010 & 40 & -0.650 & -0.33 & 0.01 & 0.83 & -0.18 & -0.81 & & \\
\hline HMean & 0.006 & 0.005 & -0.017 & 0.010 & 40 & +1.908 & 0.01 & 0.16 & -0.30 & -0.28 & 0.62 & -0.56 & \\
\hline HCorr & 0.371 & 0.375 & -0.256 & 0.778 & 40 & +0.439 & 0.45 & -0.11 & -0.81 & 0.51 & 0.55 & -0.62 & -0.04 \\
\hline
\end{tabular}

Notes. H (Hedged) returns are based on EMBI for emerging markets and hedged series for industrial countries. Israel, Pakis tan, Russia, Morocco, and Ecuador are omitted because of lack of data. T-stat is the t-statistic from a regression of holdings on the characteristic (and a constant).

(c) Holdings of Local-Currency-Denominated Bonds

\begin{tabular}{|c|c|c|c|c|c|c|c|c|c|c|c|c|c|}
\hline & Mean & Standard & Min & $\operatorname{Max}$ & Nobs & t-stat & \multicolumn{7}{|c|}{ Correlations } \\
\hline & & & & & & & BdDev & Trade & Rating & Open & IHSharpe & IHVar & IHMean \\
\hline BdDev & 0.722 & 0.681 & 0.121 & 4.230 & 48 & +0.893 & & & & & & & \\
\hline Trade & 0.107 & 0.114 & 0.010 & 0.544 & 48 & +0.423 & -0.09 & & & & & & \\
\hline Rating & 6.521 & 5.411 & 1 & 20 & 48 & -3.011 & -0.49 & -0.01 & & & & & \\
\hline Open & 3.185 & 0.839 & 1.5 & 4 & 46 & +2.008 & 0.35 & 0.02 & -0.53 & & & & \\
\hline IHSharpe & 0.092 & 0.194 & -0.406 & 0.578 & 42 & +1.994 & 0.34 & 0.01 & -0.56 & 0.11 & & & \\
\hline IHVar & 0.003 & 0.005 & 0.000 & 0.023 & 42 & -2.633 & -0.33 & 0.02 & 0.75 & -0.38 & -0.49 & & \\
\hline IHMean & 0.003 & 0.010 & -0.032 & 0.042 & 42 & +1.052 & 0.13 & 0.07 & -0.35 & -0.13 & 0.85 & -0.42 & \\
\hline IHCorr & 0.325 & 0.384 & -0.302 & 0.778 & 42 & +3.064 & 0.48 & -0.09 & -0.83 & 0.62 & 0.50 & -0.65 & 0.18 \\
\hline
\end{tabular}

Notes. IH (Incomplete Hedged) returns series consist of hedged returns for industrial countries and, for emerging markets, returns based on EMBI with exchange rate changes. Russia and Ecuador are omitted because of lack of data. T-stat is the t-statistic from a regression of holdings on the characteristic (and a constant). 
Table 4. Regression Results: Determinants of US Investors' Foreign Bond Portfolio Weights

\begin{tabular}{|c|c|c|c|c|c|c|c|}
\hline & \multicolumn{2}{|c|}{ Total Holdings } & \multicolumn{2}{|c|}{ \$-denominated } & \multicolumn{3}{|c|}{ Local-Currency-Denominated } \\
\hline & (1) & (2) & (3) & (4) & (5) & (6) & (7) \\
\hline Trade & $\begin{array}{c}0.119^{*} \\
(0.063)\end{array}$ & $\begin{array}{c}0.136^{*} \\
(0.075)\end{array}$ & $\begin{array}{c}0.389^{*} \\
(0.211)\end{array}$ & $\begin{array}{c}0.353^{*} \\
(0.217)\end{array}$ & $\begin{array}{c}0.013 \\
(0.022)\end{array}$ & $\begin{array}{c}0.006 \\
(0.025)\end{array}$ & $\begin{array}{c}0.003 \\
(0.025)\end{array}$ \\
\hline BdDev & $\begin{array}{c}0.0001 \\
(0.013)\end{array}$ & $\begin{array}{l}-0.007 \\
(0.017)\end{array}$ & $\begin{array}{c}0.060 \\
(0.040)\end{array}$ & $\begin{array}{c}0.059 \\
(0.039)\end{array}$ & $\begin{array}{l}-0.004 \\
(0.005)\end{array}$ & $\begin{array}{l}-0.003 \\
(0.005)\end{array}$ & $\begin{array}{l}-0.006 \\
(0.006)\end{array}$ \\
\hline Open & $\begin{array}{l}0.044^{* * *} \\
(0.011)\end{array}$ & $\begin{array}{l}0.033^{* *} \\
(0.013)\end{array}$ & $\begin{array}{c}0.026 \\
(0.024)\end{array}$ & $\begin{array}{c}0.031 \\
(0.024)\end{array}$ & $\begin{array}{c}0.002 \\
(0.004)\end{array}$ & $\begin{array}{c}0.007 \\
(0.005)\end{array}$ & $\begin{array}{c}0.004 \\
(0.004)\end{array}$ \\
\hline Corr & $\begin{array}{l}-0.071^{* * *} \\
(0.026)\end{array}$ & $\begin{array}{c}-0.053^{*} \\
(0.029)\end{array}$ & $\begin{array}{c}-0.057 \\
(0.065)\end{array}$ & $\begin{array}{c}-0.008 \\
(0.073)\end{array}$ & $\begin{array}{l}0.022^{* * *} \\
(0.008)\end{array}$ & & \\
\hline Sharpe & $\begin{array}{l}0.116^{* *} \\
(0.052)\end{array}$ & $\begin{array}{r}0.037 \\
(0.063)\end{array}$ & $\begin{array}{c}0.072 \\
(0.153)\end{array}$ & & $\begin{array}{c}-0.002 \\
(0.008)\end{array}$ & & \\
\hline Mean & & & & $\begin{array}{c}6.564^{*} \\
(3.541)\end{array}$ & & $\begin{array}{c}0.127 \\
(0.155)\end{array}$ & $\begin{array}{c}0.015 \\
(0.143)\end{array}$ \\
\hline Variance & & & & $\begin{array}{c}9.167 \\
(9.417)\end{array}$ & & $\begin{array}{l}-0.802^{* *} \\
(0.359)\end{array}$ & $\begin{array}{c}0.170 \\
(0.318)\end{array}$ \\
\hline Rating & & & & & & & $\begin{array}{l}-0.002^{* *} \\
(0.001)\end{array}$ \\
\hline $\begin{array}{l}\text { Nobs } \\
\text { Adj. } R^{2}\end{array}$ & $\begin{array}{c}44 \\
0.353\end{array}$ & $\begin{array}{c}42 \\
0.218\end{array}$ & $\begin{array}{c}40 \\
0.163\end{array}$ & $\begin{array}{c}40 \\
0.164\end{array}$ & $\begin{array}{c}42 \\
0.068\end{array}$ & $\begin{array}{c}42 \\
0.019\end{array}$ & $\begin{array}{c}42 \\
0.063\end{array}$ \\
\hline
\end{tabular}

Notes. Dependent variable is the share of a nation's total, dollar-denominated, or local-currency denominated debt held by US investors. Hedging assumptions for returns variables (Corr, Sharpe, Mean, and Var) vary across columns. For Total Holdings, returns variables are generated using dollardenominated returns for emerging markets and, alternatively, unhedged (in column 1) and hedged (in column 2) local currency returns for industrial countries. For dollar holdings (columns 3 and 4), hedged returns series are used for industrial countries. For local currency holdings (columns 5-7), local currency returns are used for emerging markets and hedged returns for industrial countries; results using unhedged returns for industrial countries (not shown) are similar, but Corr becomes insignificant. Russia and Ecuador are omitted throughout because of a lack of data. Israel, Pakistan, and Morocco are omitted from columns (3) and (4). Newey and West (1987) standard errors are in parentheses. ***, **, and * indicate significance at the 1,5 , and 10 percent levels respectively. 
Table 5. Regression Results: Reallocations in Bond and Equity Portfolios

\begin{tabular}{|c|c|c|c|c|c|c|c|}
\hline & \multicolumn{3}{|c|}{ Bonds } & \multicolumn{4}{|c|}{ Equities } \\
\hline & (1) & (2) & (3) & (4) & (5) & (6) & (7) \\
\hline BdDev97 & $\begin{array}{c}0.042^{*} \\
(0.021)\end{array}$ & $\begin{array}{c}0.057^{* * *} \\
(0.021)\end{array}$ & $\begin{array}{c}0.074^{* * *} \\
(0.021)\end{array}$ & & & & \\
\hline DBdDev & $\begin{array}{l}-0.007 \\
(0.011)\end{array}$ & $\begin{array}{c}0.028 \\
(0.034)\end{array}$ & $\begin{array}{c}0.023 \\
(0.033)\end{array}$ & & & & \\
\hline EqDev97 & & & & $\begin{array}{l}0.020^{*} \\
(0.011)\end{array}$ & $\begin{array}{l}0.019^{*} \\
(0.011)\end{array}$ & $\begin{array}{l}0.019^{*} \\
(0.012)\end{array}$ & $\begin{array}{c}0.018 \\
(0.011)\end{array}$ \\
\hline Rating97 & $\begin{array}{c}-0.005^{* *} \\
(0.002)\end{array}$ & $\begin{array}{l}-0.003 \\
(0.002)\end{array}$ & & $\begin{array}{c}-0.002^{* *} \\
(0.001)\end{array}$ & $\begin{array}{l}-0.002^{*} \\
(0.001)\end{array}$ & $\begin{array}{l}-0.002^{*} \\
(0.001)\end{array}$ & $\begin{array}{l}-0.002 \\
(0.002)\end{array}$ \\
\hline DRating & $\begin{array}{c}-0.011^{* * *} \\
(0.004)\end{array}$ & $\begin{array}{c}-0.008^{* * *} \\
(0.003)\end{array}$ & & $\begin{array}{c}-0.008^{*} \\
(0.004)\end{array}$ & $\begin{array}{c}-0.007 \\
(0.005)\end{array}$ & & \\
\hline Sharpe01 & & $\begin{array}{c}0.202^{* * *} \\
(0.041)\end{array}$ & & & $\begin{array}{r}0.107 \\
(0.090)\end{array}$ & $\begin{array}{l}0.182^{* *} \\
(0.081)\end{array}$ & \\
\hline Mean & & & $\begin{array}{l}3.00^{* * *} \\
(0.595)\end{array}$ & & & & $\begin{array}{l}1.79^{* * *} \\
(0.629)\end{array}$ \\
\hline Variance & & & $\begin{array}{c}-10.89^{* * *} \\
(3.20)\end{array}$ & & & & $\begin{array}{c}0.586 \\
(0.559)\end{array}$ \\
\hline $\begin{array}{l}\text { Nobs } \\
\text { Adi. } R^{2}\end{array}$ & $\begin{array}{c}43 \\
0.419\end{array}$ & $\begin{array}{c}39 \\
0.515\end{array}$ & $\begin{array}{c}39 \\
0.501\end{array}$ & $\begin{array}{c}49 \\
0.236\end{array}$ & $\begin{array}{c}49 \\
0.240\end{array}$ & $\begin{array}{c}49 \\
0.188\end{array}$ & $\begin{array}{c}50 \\
0.200\end{array}$ \\
\hline
\end{tabular}

Notes. Dependent variables are changes from 1997 to 2001. For bonds, the change in the share of a nation's bond market (net of price effects) held by U.S. investors, and, for equities, the change in the share of a nation's equity market held by US investors. In the bonds regressions, (i) returns variables are based on hedged series for industrial countries and dollar-based bond indices for emerging markets and (ii)

Russia, Ecuador, Venezuela, and Uruguay are omitted because of a lack of data. Newey and West (1987) standard errors are in parentheses. $* * *, *$, and $*$ indicate significance at the 1,5 , and 10 percent levels respectively. 
Table 6. Measures of Local-Currency Bond Market Development

\begin{tabular}{|l|l|l|l|l|l|}
\hline \multirow{2}{*}{} & \multicolumn{2}{|c|}{ International Bonds } & \multicolumn{3}{c|}{ Total Bonds Outstanding } \\
\cline { 3 - 6 } & \$ billions & $\begin{array}{l}\text { \% denominated } \\
\text { in local currency }\end{array}$ & \$ billions & $\%$ of total & $\%$ of GDP \\
\hline Argentina & 89 & $3 \%$ & 113 & $16 \%$ & $7 \%$ \\
\hline Chile & 9 & $0 \%$ & 41 & $73 \%$ & $38 \%$ \\
\hline UK & 677 & $50 \%$ & 1313 & $74 \%$ & $68 \%$ \\
\hline
\end{tabular}


Table 7a. Regression Results: Local Currency Bond Market Development ${ }^{\mathrm{a}}$

\begin{tabular}{|c|c|c|c|c|c|}
\hline & Bivariate & & & ariate & \\
\hline $\begin{array}{l}\text { Inflation - } \\
\text { Variance }\end{array}$ & $\begin{array}{l}\stackrel{(1)}{(1)}^{* 2.441^{* * *}} \\
(0.471)\end{array}$ & $\begin{array}{c}\mathbf{( 2 )} \\
-1.280^{* * * *} \\
(0.380)\end{array}$ & (3) & $\begin{array}{c}\mathbf{( 4 )} \\
-1.311^{\text {**** }} \\
(0.443)\end{array}$ & (5) \\
\hline $\begin{array}{l}\text { Inflation - } \\
\text { Mean }\end{array}$ & $\begin{array}{l}-2.476^{* * *} \\
(0.717)\end{array}$ & & $\begin{array}{c}-1.078^{* * *} \\
(0.320)\end{array}$ & & $\begin{array}{l}-1.139^{* * *} \\
(0.345)\end{array}$ \\
\hline $\begin{array}{l}\text { GDP Per } \\
\text { Capita }\end{array}$ & $\begin{array}{l}0.446^{* * * *} \\
(0.114)\end{array}$ & $\begin{array}{c}0.429^{* * *} \\
(0.133)\end{array}$ & $\begin{array}{c}0.410^{* * * *} \\
(0.134)\end{array}$ & & \\
\hline GDP & $\begin{array}{c}0.044 \\
(0.077)\end{array}$ & $\begin{array}{c}0.012 \\
(0.067)\end{array}$ & $\begin{array}{c}0.011 \\
(0.066)\end{array}$ & $\begin{array}{c}0.000 \\
(0.073)\end{array}$ & $\begin{array}{c}0.000 \\
(0.072)\end{array}$ \\
\hline $\begin{array}{l}\text { Rule of } \\
\text { Law }\end{array}$ & $\begin{array}{l}0.123^{* * *} \\
(0.028)\end{array}$ & & & $\begin{array}{l}0.119^{* * *} \\
(0.036)\end{array}$ & $\begin{array}{l}0.113^{* * *} \\
(0.036)\end{array}$ \\
\hline $\begin{array}{l}\text { Adj. } R^{2} \\
\text { Nobs }\end{array}$ & $\begin{array}{l}\text { n.a. } \\
\text { n.a. }\end{array}$ & $\begin{array}{c}0.299 \\
49\end{array}$ & $\begin{array}{c}0.305 \\
49\end{array}$ & $\begin{array}{c}0.262 \\
49\end{array}$ & $\begin{array}{c}0.269 \\
49\end{array}$ \\
\hline
\end{tabular}

${ }^{a}$ Dependent variable is the size a nation's local-currency-denominated bond market (excluding central bank holdings) divided by GDP.

Table 7b. Regression Results: Share of Outstanding Bonds Denominated in Local Currency

\begin{tabular}{|c|c|c|c|c|c|}
\hline & Bivariate & \multicolumn{4}{|c|}{ Multivariate } \\
\hline $\begin{array}{l}\text { Inflation - } \\
\text { Variance }\end{array}$ & $\begin{array}{c}\mathbf{( 1 )}^{* * *} \\
-2.550^{* *} \\
(0.173)\end{array}$ & $\begin{array}{c}\mathbf{( 2 )} \\
-2.708^{* * *} \\
(0.192)\end{array}$ & (3) & $\begin{array}{c}\mathbf{( 4 )} \\
-2.573^{* * *} \\
(0.210)\end{array}$ & (5) \\
\hline $\begin{array}{l}\text { Inflation - } \\
\text { Mean }\end{array}$ & $\begin{array}{c}-1.888^{* * *} \\
(0.247)\end{array}$ & & $\begin{array}{c}-2.000^{* * *} \\
(0.245)\end{array}$ & & $\begin{array}{l}-1.836^{* * *} \\
(0.280)\end{array}$ \\
\hline $\begin{array}{l}\text { GDP Per } \\
\text { Capita }\end{array}$ & $\begin{array}{c}0.052 \\
(0.052)\end{array}$ & $\begin{array}{c}0.004 \\
(0.040)\end{array}$ & $\begin{array}{l}-0.027 \\
(0.038)\end{array}$ & & \\
\hline GDP & $\begin{array}{c}0.057^{* * *} \\
(0.020)\end{array}$ & $\begin{array}{c}0.064^{* * * *} \\
(0.019)\end{array}$ & $\begin{array}{c}0.060^{* * * *} \\
(0.017)\end{array}$ & $\begin{array}{l}0.058^{* * *} \\
(0.017)\end{array}$ & $\begin{array}{c}0.056^{* * *} \\
(0.016)\end{array}$ \\
\hline $\begin{array}{l}\text { Rule of } \\
\text { Law }\end{array}$ & $\begin{array}{l}0.029^{* * *} \\
(0.014)\end{array}$ & & & $\begin{array}{c}0.014 \\
(0.012)\end{array}$ & $\begin{array}{c}0.006 \\
(0.013)\end{array}$ \\
\hline $\begin{array}{l}\text { Adj. } R^{2} \\
\text { Nobs }\end{array}$ & $\begin{array}{l}\text { n.a. } \\
\text { n.a. }\end{array}$ & $\begin{array}{c}0.293 \\
49\end{array}$ & $\begin{array}{c}0.338 \\
49\end{array}$ & $\begin{array}{c}0.311 \\
49\end{array}$ & $\begin{array}{c}0.335 \\
49\end{array}$ \\
\hline
\end{tabular}

Notes. In Tables 7a and 7b, Pakistan and Ecuador were dropped due to lack of data. Newey and West (1987) standard errors are in parentheses. ***,**, and * indicate significance at the 1,5 , and 10 percent levels respectively. 
Table 8a. Regression Results: Local Currency Bond Market Development (excluding outliers) ${ }^{\mathrm{a}}$

\begin{tabular}{|c|c|c|c|c|c|}
\hline & Bivariate & & & ariate & \\
\hline $\begin{array}{l}\text { Inflation - } \\
\text { Variance }\end{array}$ & $\begin{array}{c}(\mathbf{1}) \\
-328^{* * * *} \\
(70)\end{array}$ & $\begin{array}{c}(2) \\
-155^{* * *} \\
(45.2)\end{array}$ & (3) & $\begin{array}{c}(\mathbf{4}) \\
-160^{* * *} \\
(40.4)\end{array}$ & (5) \\
\hline $\begin{array}{l}\text { Inflation - } \\
\text { Mean }\end{array}$ & $\begin{array}{c}-12.7^{* * *} \\
(2.93)\end{array}$ & & $\begin{array}{c}-5.893^{* * *} \\
(1.812)\end{array}$ & & $\begin{array}{c}-5.817^{* * *} \\
(1.508)\end{array}$ \\
\hline $\begin{array}{l}\text { GDP Per } \\
\text { Capita }\end{array}$ & $\begin{array}{c}0.338^{* * * *} \\
(0.068)\end{array}$ & $\begin{array}{c}0.229^{* * * *} \\
(0.062)\end{array}$ & $\begin{array}{c}0.225^{* * * *} \\
(0.059)\end{array}$ & & \\
\hline GDP & $\begin{array}{c}0.121^{* * *} \\
(0.042)\end{array}$ & $\begin{array}{l}0.076^{* *} \\
(0.032)\end{array}$ & $\begin{array}{l}0.072^{* *} \\
(0.033)\end{array}$ & $\begin{array}{c}0.070^{* *} \\
(0.034)\end{array}$ & $\begin{array}{c}0.067^{* *} \\
(0.034)\end{array}$ \\
\hline $\begin{array}{l}\text { Rule of } \\
\text { Law }\end{array}$ & $\begin{array}{l}0.099^{* * *} \\
(0.020)\end{array}$ & & & $\begin{array}{c}0.066^{* *} \\
(0.022)\end{array}$ & $\begin{array}{l}0.064^{* * *} \\
(0.022)\end{array}$ \\
\hline $\begin{array}{l}\text { Adj. } R^{2} \\
\text { Nobs }\end{array}$ & $\begin{array}{l}\text { n.a. } \\
\text { n.a. }\end{array}$ & $\begin{array}{c}0.385 \\
45\end{array}$ & $\begin{array}{c}0.385 \\
45\end{array}$ & $\begin{array}{c}0.384 \\
45\end{array}$ & $\begin{array}{c}0.379 \\
45\end{array}$ \\
\hline
\end{tabular}

${ }^{a}$ Dependent variable is the size a nation's local-currency-denominated bond market (excluding central bank holdings) divided by GDP.

Table 8b. Regression Results: Share of Outstanding Bonds Denominated in Local Currency (excluding outliers)

\begin{tabular}{|c|c|c|c|c|c|}
\hline & Bivariate & & & ariate & \\
\hline & (1) & (2) & (3) & (4) & (5) \\
\hline Inflation - & $-152^{* * *}$ & $-160^{* *}$ & & $-126^{*}$ & \\
\hline Variance & (75.4) & $(72.8)$ & & (74.8) & \\
\hline Inflation - & $-6.33^{* * *}$ & & $-6.856^{* * *}$ & & $-5.603^{* *}$ \\
\hline Mean & $(1.84)$ & & (1.922) & & $(2.180)$ \\
\hline GDP Per & 0.033 & -0.069 & $-0.083^{*}$ & & \\
\hline Capita & $(0.051)$ & $(0.045)$ & $(0.045)$ & & \\
\hline GDP & $0.067^{* * *}$ & $0.058^{* *}$ & $0.053^{* * *}$ & $0.054^{* * *}$ & $0.050^{* * *}$ \\
\hline & $(0.021)$ & $(0.015)$ & $(0.013)$ & $(0.016)$ & $(0.015)$ \\
\hline Rule of & $0.024^{*}$ & & & -0.001 & -0.007 \\
\hline Law & $(0.014)$ & & & $(0.014)$ & $(0.017)$ \\
\hline Adj. $R^{2}$ & n.a. & 0.260 & 0.301 & 0.225 & 0.255 \\
\hline Nobs & n.a. & 45 & 45 & 45 & 45 \\
\hline
\end{tabular}

Notes. In Tables 8a and 8b, in addition to Pakistan and Ecuador (lack of data), we drop three inflation outliers (Russia, Brazil, and Turkey) and one bond market development outlier (Luxembourg). Newey and West (1987) standard errors are in parentheses. $*^{* *}, * *$, and $*$ indicate significance at the 1,5 , and 10 percent levels respectively. 


\section{Figure 1}

\section{Efficient Frontiers for International Bond Portfolios}

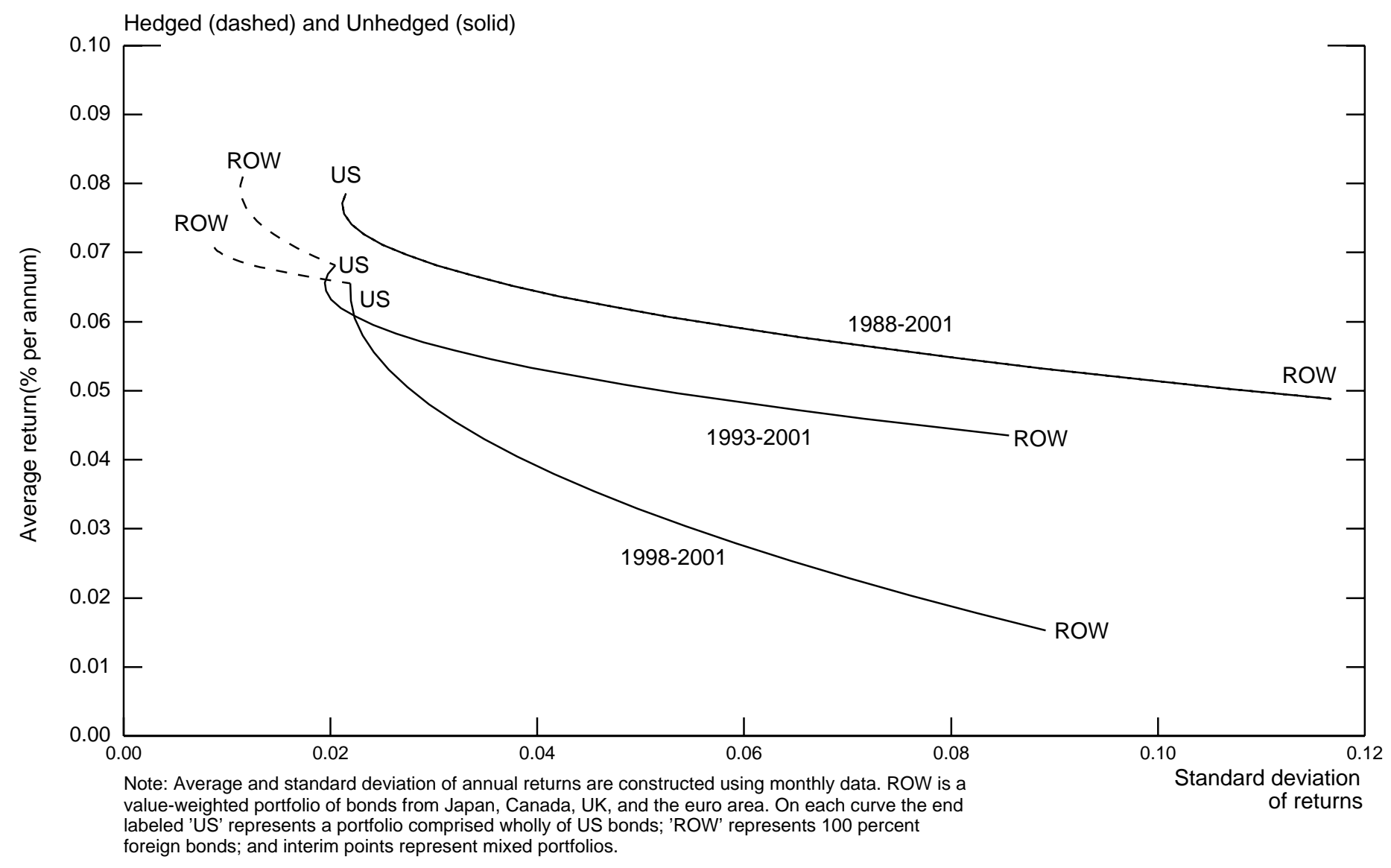

